\title{
Proses Kampanye Public Relations "Youtube Broadcast Box” Di Media
}

\section{Sosial}

\author{
Merina Lydia Isabella Natashya, Hanny Hafiar, dan Aat Ruchiat Nugraha \\ Email:hannyhafiar@gmail.com \\ Program Studi Ilmu Hubungan Masyarakat Fakultas Ilmu Komunikasi \\ Universitas Padjadjaran
}

\begin{abstract}
ABSTRAK
Perkembangan strategi brand suatu produk sekarang ini semakin kreatif dengan menggunakan berbagai media komunikasi untuk dapat mempersuasi publik. Keberadaan suatu brand dapat dikomunikasikan melalui pendekatan emotional feel, attitude change, dan behaviour yang dilakukan terhadap target sasarannya. Youtube sebagai provider yang memiliki peran yang kuat dalam menyimpan data informasi yang paling besar berupa tayangan film dapat memberikan kontribusi untuk membangun dan meningkatkan brand experience produk tertentu.

Tujuan penelitian ini adalah untuk mengetahui proses kampanye yang dilakukan oleh Youtube Broadcast Box dalam upaya meningkatkan brand experience terhadap Youtubers Indonesia. Adapun metode penelitian yang digunakan adalah deskriptif dengan teknik pengumpulan data melalui wawancara terstruktur, observasi, dan studi pustaka. Dalam teknik penentuan key informan, penelitian ini menggunakan teknik purposive sampling.

Hasil penelitian menunjukkan bahwa proses kampanye public relations yang dilakukan oleh Youtube Broadcast Box telah dapat meningkatkan brand experience para Youtubers Indonesia yang dibuktikan dengan banyaknya kunjungan dari audience yang ingin menonton tayangan di Youtube secara berkelanjutan untuk berbagai kegiatan yang dianggap memiliki nilai informasi bagi publik.
\end{abstract}

Kata Kunci : Kampanye Public Relations, Brand Experience, dan Youtube Broadcast Box

\section{ABSTRACT}

The development of the brand strategy a product now this is getting creative by the use of various media of public communication persuasive. The existence of a brand can be communicated with the emotional feel, attitude change, and behaviour was done with their targets. Youtube as providers having role strong in store data information the greatest of impressions film to give contribution to build and improve brand experience certain products.

The purpose of this research is to aware of the campaign done by youtube broadcast box in order to increase brand experience of youtubers Indonesia. As for research methodology used is descriptive to technique data collection through interviews structured, observation, and the literature study. The technique of the determination of key informants, this research using a technique purposive sampling.

The research results show that the process of public relations campaign conducted by broadcast box of youtube has been able to increase brand experience the youtubers indonesia which is evidenced by the number of visits from audience who want to watch impressions on youtube in a sustainable way for various activities being regarded as having the value of information to the public.

Keywords: public relations campaign, brand experience, and youtube broadcast box 


\section{PENDAHULUAN}

Dikenal, belum tentu dicintai. Fakta inilah seringkali menjadi bumerang bagi sebuah brand yang awareness-nya tinggi. Kondisi ini lah yang dialami oleh Youtube Indonesia, yang dimana menurut hasil riset Google Indonesia yang menyatakan bahwa masih banyak pengguna Youtube khususnya di negara berkembang yang masih belum tahu fungsi yang dimiliki oleh Youtube sendiri dan bagaimana cara publik menyalurkan kreatifitas ke dalam bentuk video menyebabkan banyaknya kreator yang berpindah kepada sosial media lain seperti Tumblr, Vine dan Twitter yang penggunaannya lebih mudah daripada Youtube. Youtube merupakan salah satu dari segelintir provider yang sangat diminati oleh publik ketika berkaitan dengan jasa tayangan audio-visual di dunia maya. Namun, kendati berperan besar sebagai penyedia data informasi yang berupa audio-visual, Youtube tidak terlepas dari terpaan isu-isu negatif dalam menghadapi semakin cepatnya perkembangan teknologi informasi yang kreatif dan memiliki nilai bisnis. Padahal, sebagian masyarakat banyak menggunakan Youtube sebagai ajang menyebarkan informasi yang bersifat hiburan, pendidikan, politik, dan sebagainya. Nilai informasi dalam bentuk audio-visual yang dimanfaatkan oleh masyarakat belum dapat menunjukkan Youtube sebagai sebuah produk yang elegan, namun dipersepsi oleh masyarakat sebagai sebuah brand media sosial yang berkaitan dengan tayangan film.

Berdasarkan salah satu fakta tersebut, Youtube meluncurkan program komunikasi publik melalui kampanye Youtube Broadcast Box yang membuka peluang bagi masyarakat untuk belajar dan mengembangkan kreatifitas membuat konten audio visual yang benar dan dapat mengoptimalkan fungsi Youtube yang maksimal sebagai media penyebaran informasi yang dihasilkan dari kampanye tersebut. Youtube Broadcast Box sendiri merupakan sebuah mini studio yang dilengkapi dengan kamera profesional, props, dan peralatan editing untuk menyediakan praktik langsung bagi masyarakat yang ingin mendapatkan pelatihan menyeluruh tentang meraih sukses berbisnis maupun ketenaran melalui Youtube. Di dalam Youtube Broadcast Box, para kreator dapat mempelajari kemudahan menggugah video ke situs Youtube, dengan panduan langsung dari pakar video. Apabila masyarakat telah paham dan dapat membuat video, masyarakat dapat mengikuti workshop tentang fungsi dan manfaat menggunakan Youtube, di mana narasumber workshop ini adalah para pakar dari Youtube yang akan berbagi tips dan trik untuk mengembangkan channel melalui Youtube Partnership Program, serta melindungi konten publik yang terdapat di 
dunia maya. Workshop ini, mengundang kreator-kreator Youtube lokal yang telah menguasai seni membuat video menjadi viral di media maya, khususnya.

Adanya pengalaman dari masyarakat disaat berinteraksi dengan Youtube hampir menyatakan bahwa Youtube itu adalah sebagai brand, bukan sebuah produk. Pengalaman seperti inilah yang membuat Youtube mempertahankan top of mind di publiknya. Dengan demikian, esensi dari sebuah brand experience dari suatu produk atau jasa yaitu membangun interaksi yang lebih berarti dan memiliki dampak jangka panjang. Dalam upaya mengubah persepsi masyarakat mengenai Youtube agar dikenal sebagai sebuah brand yang elegan perlu dilakukan suatu kampanye yang berkesinambungan dengan target sasarannya paling utama remaja.

Suatu kampanye publik yang bertujuan untuk mengubah perilaku manusia terdapat beberapa langkah teknis yang perlu dilakukan secara strategis dan pasti agar kampanye dapat berjalan dengan sukses mematuhi proses atau tahapan kampanye yang matang dan efektif. Merencanakan sebuah kampanye yang sukses dan berhasil bukanlah hal yang mudah, tetapi membutuhkan suatu perencanaan yang dibuat dan terkadang tidak sesuai dengan apa yang diharapkan oleh manajemen/pimpinan. Atas dasar kondisi yang dihadapi tersebut, Youtube
Indonesia mengadakan kampanye Youtube Broadcast Box dengan tujuan untuk memperkenalkan produk perusahaan secara lebih terbuka, mendalam, dan komprehensif kepada publiknya, khususnya para remaja. Kampanye Youtube Broadcast Box dilaksanakan melalui workshop dengan menyasar semua usia dengan primary target-nya yaitu para kreator dan komunitas pecinta youtube atau biasa disebut Youtubers.

Disaat kampanye Youtube Broadcast Box dilakukan ada beberapa kendala yang dialami selama proses perencanaan, diantaranya adalah kurangnya sumber daya manusia yang dapat menentukan strategi yang akan dilakukan dan penentuan alokasi waktu kampanye yang efektif. Sedangkan, ketika kampanye Youtube Broadcast Box mulai dijalankan terdapat beberapa kendala yang terjadi yaitu tidak terfokusnya target segmentasi sehingga dapat menyebabkan jumlah pengunjung yang membludak karena tidak terprediksi dan mengakibatkan acara menjadi tidak kondusif.

Dalam hal target segmentasi yang terlalu luas disaat penentuan kampanye dapat menjadi salah satu yang menyebabkan tim Youtube Indonesia mengalami kesulitan dalam mengatur para pengunjung yang datang. Kondisi seperti ini, memberikan kebingungan bagi pengelola dalam menentukan kategori peserta, atau pengunjung yang bersifat biasa 
atau tergabung dalam suatu komunitas tertentu, seperti anggota komunitas Youtubers Indonesia. Membludaknya pengunjung yang datang akhirnya mengakibatkan pesan yang ingin disampaikan Youtube Indonesia kepada target sasaran menjadi tidak tersampaikan dengan baik. Yang pada akhirnya, dampak dari pesan yang tidak tersampaikan ini, sangat terasa ketika evaluasi berlangsung bahwa data statistik video upload Youtube hanya mengalami sedikit peningkatan jauh di bawah ekspetasi yang diharapkan tim Youtube Indonesia. Berdasarkan pemaparan di atas dapat dapat dijelaskan dengan cara "Bagaimana proses kampanye public relations yang dilakukan oleh Youtube agar dapat menghasilkan jumlah penonton yang cukup signifikan dan efektif bagi sasarannya”.

\section{KAJIAN PUSTAKA}

Menurut Venus (2004), kampanye pada hakikatnya adalah tindakan komunikasi yang bersifat goal oriented. Pada kegiatan kampanye selalu ada tujuan yang hendak dicapai. Pencapaian tujuan tersebut tentu saja tidak dapat dilakukan melakukan tindakan yang sekenanya, melainkan harus didasari pengorganisasian tindakan secara sistematis dan strategis. Hal ini menunjukkan bahwa kegiatan kampanye membutuhkan sentuhan manajemen yakni kemampuan merancang, melaksanakan, mengendalikan dan mengevaluasi suatu program kegiatan secara rasional, realistis, efisien dan efektif.

Praktik tahapan kegiatan kampanye bukanlah hal baru. Sejak awal, kegiatan kampanye selalu meliputi tahapan perencanaan, pelaksanaan dan hingga evaluasi. Perbedaanya adalah pada masa kini berbagai tahapan tersebut dibakukan dan diformalkan dengan istilah manajemen kampanye yakni proses pengelolaan kegiatan kampanye secara efektif dan efisien dengan memanfaatkan seluruh sumber daya yang ada guna mencapai tujuan yang telah ditetapkan. Dengan dimasukkannya unsur manajerial dalam pengelolaan kampanye diharapkan peluang keberhasilan pencapaian tujuan kampanye menjadi lebih terbuka dan lebih besar.

\section{Unsur Perencanaan Kampanye}

Menurut Gregory (dalam Venus, 2004) mengatakan terdapat 7 langkah dalam merencanakan sebuah kampanye, yaitu : Analisis Masalah, Tujuan, Khalayak sasaran, Pesan, Strategi dan Taktik, Alokasi Waktu dan Sumber Daya kemudian Bentuk evaluasi.

\section{Unsur Pelaksanaan Kampanye}

1. Realisasi Unsur - Unsur Pokok Kampanye

Kegiatan ini meliputi: perekrutan dan pelatihan personel kampanye PR, mengonstruksi pesan, menyeleksi pesan kampanye PR dan 
menyeleksi saluran kampanye.

(Venus, 2004).

2. Uji Coba Rencana Kampanye

Uji coba terhadap suatu rancangan dilakukan untuk menyusun strategi (pesan, media dan penyampai pesan) yang paling sesuai dengan situasi dan kondisi yang dihadapi. (Venus, 2004).

3. Tindakan dan Pemantauan Kampanye

Harus dipahami bahwa tindakan kampanye bukanlah tindakan yang kaku dan parsial, tetapi bersifat adaptif (menyesuaikan), antisipatif (cepat tanggap), integratif (pemersatu), dan berorientasi pada pemecahan masalah. (Venus, 2004)

4. Laporan Kemajuan

Laporan kemajuan merupakan dokumen yang sangat penting bukan hanya bagi manajer tetapi juga pelaksana kampanye secara keseluruhan. (Venus, 2004)

\section{Unsur Evaluasi Kampanye}

Menurut Morrisan (2005), evaluasi kampanye terdiri dari 3 tahapan yaitu evaluasi tahap persiapan, evaluasi tahap pelaksanaan dan evaluasi tahap efek.

1. Evaluasi Tahap Persiapan

Langkah pertama evaluasi ini adalah untuk menilai kecukupan atau kelengkapan pengumpulan informasi atau kegaitan intelejen yang akan digunakan dalam proses selanjutnya. Langkag kedua dalam kegiatan riset evaluasi adalah membahas kesesuaian program dan kesesuaian strategi pesan dan taktik yang dilakukan (appropriatness of message and activity content). Pada tahapan ini dilakukan suatu tinjauan mengenai seberapa baik suatu program dapat memenuhi permintaan atau kebutuhan situasi.

2. Evaluasi Tahap Pelaksanaan

Dalam mengevaluasi tahap implementasi, praktisi humas mengumpulkan bukti - bukti kegiatan, misalnya guntingan artikel di surat kabar, bukti penayangan (siaran) televisi dan radio, daftar hadir yang menunjukkan jumlah peserta atau undangan suatu pertemuan. Catatan atas segala kegiatan pada tahap implementasi program sangat penting guna membantu melaksanakan riset evaluasi pada tahap ini. Tanpa dokumentasi yang lengkap, maka praktisi humas tidak akan mengetahui apa yang sudah berjalan dengan baik, apa yang masih menjadi kelemahan, apa yang salah, dan mengapa hal itu terjadi.

3. Evaluasi Tahap Efek

Pengukuran efek (impact measurement) mencatat seberapa 
jauh hasil yang telah dicapai untuk masing - masing target khalayak maupun keseluruhannya sebagaimana yang dinyatakan dalam tujuan program.

\section{METODE PENELITIAN}

Dalam penelitian ini menggunakan penelitian metode dekriptif. Metode deskriptif adalah suatu metode dalam meneliti status sekelompok manusia, suatu objek, suatu set kondisi, suatu sistem pemikiran, ataupun suatu kelas periwista pada masa sekarang (Nazir, 2006). Tujuan dari penelitian deskriptif ini adalah untuk membuat deskripsi, gambaran atau lukisan secara sistematis, faktual dan akurat mengenai fakta-fakta, sifat-sifat atau hubungan antar fenomena yang diselidiki. Pada penelitian ini penulis menggunakan narasumber untuk mendapatkan data, yaitu orang-orang yang tergabung dalam komunitas Youtubers Indonesia. Adapun pengambilan narasumber dilakukan berdasarkan teknik purposive sampling. Purposive Sampling adalah teknik pengambilan sumber data dengan pertimbangan tertentu (Sugiyono, 2011: 215). Pertimbangan tertentu ini, misalnya orang tersebut yang dianggap paling tahu tentang apa yang kita harapkan, atau mungkin dia sebagai penguasa sehingga akan memudahkan peneliti menjalani obyek/situasi sosial yang diteliti.
HASIL DAN PEMBAHASAN Tahapan Perencanaan Kampanye Youtube Broadcast Box

1) Analisis Masalah

Dalam menentukan analisis masalah disini Youtube Indonesia berangkat dari hasil survey yang menyatakan bahwa masih banyak masyarakat Indonesia yang belum mengetahui penggunaan Youtube yang benar sehingga mereka memilih berpindah ke platform lain seperti path dan instagram. Survey ini sendiri diadakan di Jakarta dengan populasi 200 orang yang dipilih secara acak. Survey sendiri dilakukan melalui platform Youtube dengan mengisi kuisoner. Survey ini sendiri merupakan acuan untuk membuat kampanye Youtube Broadcast Box. Menurut Margono (2005) mendefinisikan survey sebagai bentuk pengamatan/penyelidikan yang kritis untuk mendapatkan keterangan yang terang dan baik terhadap suatu persoalan tertenntu dan di dalam suatu daerah tertentu. Survey umumnya bertujuan untuk mencapai generalisasi, dan sebagaian lain juga untuk membuat prediksi.Berangkat dari permasalahan tersebut, Youtube Indonesia pun berpikir bagaimana caranya mengubah persepsi masyarakat khususnya konsumen yaitu youtuber Indonesia tentang penggunanaan Youtube yang benar. Maka dari itu, Youtube Indonesia memilih menggunakan kampanye PR untuk menjawab permasalahan tersebut. Pemilihan ini berdasarkan dengan tujuan 
kampanye PR yang bertujuan untuk mengubah persepsi khalayak terhadap produk.

\section{2) Penyusunan Tujuan}

Setelah menguasai permasalahan yang ada, Youtube Indonesia mulai menetapkan tujuan atau target kerja mereka sesuai dengan apa yang ingin diluruskan dari permasalahan tersebut. Tujuan dari kampanye Youtube Broadcast Box ini sendiri tidak hanya sekedar menjawab permasalahan tentang Youtube itu sendiri tetapi juga secara garis besar Youtube Indonesia ingin menjalin hubungan dengan konsumennya yaitu Youtubers Indonesia. YoutubeIndonesia ingin agar konsumen semakin loyal terhadap produk mereka. Hal ini dilakukan dengan cara membuat Youtube Broadcast Box dimana diharapkan dapat menciptakan brand experience yaitu menggunakan produk secara langsung. Dengan terciptanya brand experience dan engagement, konsumen merasakan langsung keunggulan dan kemudahan yang dimiliki produk, kemudian menjadi loyal terhadap brand. Menurut Gregory (2000) dalam menetapkan tujuan haruslah realisitk. Menetapakan tujuan yang realistik merupakan kunci kesuksesan rencana dan kampanye PR. Tujuan tersebut memberikan dasar bagi program - program yang disusun, dengan menetapkan secara jelas keberhasilan - keberhasilan yang harus dicapai. Tujuan juga memberikan alasan untuk strategi yang diambil, menetapkan agenda untuk tindakan yang harus dilakukan, dan menyediakan tolak ukur untuk evaluasi.

\section{3) Identifikasi dan}

\section{Segmentasi Sasaran}

Untuk mempermudah proses

identifikasi dan segmentasi sasaran dilakukan pelapisan sasaran, yaitu sasaran utama, sasaran lapis satu, sasaran lapis dua dan seterusnya sesuai tujuan kampanye. Youtube Indonesia sendiri menggunakan pelapisan sasaran dalam hal menyegmentasi sasarannya. Sasaran utama dari kampanye tersebut adalah kreator dan komunitas kreatif lokal. Sasaran utama adalah sasaran yang akan "dibidik” sasaran yang potensial. Selanjutnya, ibarat sasaran tembak, tingkat potensial itu berkurang pada sasaran lapis satu dan semakin berkurang pada lapisan berikutnya. Sasaran pada lapis berikutnya ini dapat juga disebut sebagai intermediate targets. Sasaran lapis dua kampanye ini adalah konsumen semua usia.

Menurut Gregory (2000), cara termudah untuk mengelompokkan publik adalah dengan bergerak dari umum ke khusus. Pertama, buat kelompok kelompok besar untuk mengidentifikasi hubungan mereka dengan organisasi. Pecah kelompok - kelompok besar untuk mengidentifikasi hubungan mereka dengan organisasi. Pecah kelompok - kelompok tersebut dalam kelompok - kelompok 
khusus. Ini dapat dilakukan berdasarkan cakupuan geografis ataupun tingkat keaktifan yang ditunjukkan oleh masing masing kelompok, atau berdasarkan kekuatan dan pengaruh yang dihasilkan oleh kelompok tersebut. Berdasarkan hasil wawancara dengan PR Youtube Indonesia, segmentasi yang dilakukan langsung dibagi dalam dua kelompok. Kelompok pertama atau sasaran utama ada kreator dan komunitas kreatif lokal. Mereka adalah orang - orang yang punya akun dan aktif dalam meng-upload video ke dalam platform youtube. Khalayak ini dipilih Youtube Indonesia karena masih banyak dari kreator ini yang masih kesulitan mengaplikasikan Youtube dan juga masih bingung bagaimana caranya mengaplikasikan ide kreatif mereka ke dalam konten digital video. Kelompok kedua adalah masyarakat berbagai usia sesuai dengan kutipan wawancara. Kelompok ini dipilih karena Youtube Indonesia meyakini bahwa pengguna platform mereka berasal dari berbagai usia karena itu mereka tidak membatasi siapapun, berapa usia mereka, apa profesi mereka untuk ikut ke dalam kampanye Youtube Broadcast Box.

\section{4) Menentukan Pesan}

Pada tahap perencanaan pesan, yang pertama dilakukan adalah pembuat tema kampanye. Tema merupakan ide utama yang bersifat umum, sebagai induk dari berbagai pesan yang akan disampaikan kepada sasaran. Setelah tema ditentukan, barulah dilakukan pengelolaan pesan yang akan disampaikan kepada masyarakat. Pesan merupakan pernyataan spesifik dengan ruang lingkup tertentu, dan didalamnnya terkandung tema atau ide utama. (Venus, 2004:151). Tema yang dipilih oleh Youtube Indonesia untuk kampanye ini adalah "Are You The Next Digital Creator?”.

Pesan yang ingin disampaikan adalah bahwa penggunaan Youtube itu mudah dan konsumen bisa berkreasi sepuasnya dalam bentuk konten digital video. Pesan ini nantinya diharapkan dapat mengubah persepsi konsumen terhadap produk Youtube sendiri, dengan pesan tersebut konsumen diharapkan dapat termotivasi untuk mulai berkreasi untuk membuat sebuah konten digital video. Menurut Morissan (2006), terdapat teori tentang cara bagaimana menyebarkan pesan secara efektif. Teori ini dinamankan teori lingkaran titik pusat. Teori ini menyatakan bahwa suatu ide atau gagasan akan dapat diterima oleh seluruh lapisan masyarakat melalui proses yang relatif lambat melalui tahapan yang berlapis - lapis. Ide bermula dari pemikir besar yang nantinya akan diturunkan kepada lingkaran luar yaitu kelompok disekitar dan seterusnya. Teori ini menekankan pada pentingnya menggunakan opinion leader dalam 
melaksanakan sebuah kampanye.Berangkat dari teori di atas, Youtube Indonesia pun teliti dalam memilih opinion leader untuk menyebarkan pesan kepada khalayak yang dituju. Youtube Indonesia memilih Youtuber yang sudah terkenal dan profesional. Hal ini mereka lalukan karena Youtuber yang sudah terkenal dapat lebih memotivasi dan menarik minat khalayak untuk mendengar dan mengerti pesan yang ingin disampaikan perusahaan kepada khalayak. Salah satu contohnya adalah dengan mengundang Raditya Dika sebagai pembicara pada workshop yang diadakan di Jakarta. Setiap menyelenggarakan kampanye di suatu kota, Youtuber Indonesia selalu memilih Youtuber yang terkenal di daerah masing - masing dengan maksud dapat lebih memotivasi konsumen lainnya untuk aktif menyalurkan ide kreatifnya ke dalam platform Youtube.

\section{5) Strategi dan Taktik}

Strategi sendiri sangat berhubungan erat dengan tujuan dari diadakannya kampanye Youtube Broadcast Box. Tujuan dari diadakannya kampanye Youtube Broadcast Box itu sendiri adalah menciptakan brand experience dan brand engagement kepada konsumen maupun komunitas. Dengan terciptanya brand experience dan engagement, konsumen merasakan langsung keunggulan dan kemudah yang dimiliki produk, kemudian menjadi loyal terhadap brand. Maka dari itu, Youtube Indonesia pun membuat strategi yang dapat mendekatkan brand dengan konsumen yaitu dengan mengajak konsumen untuk langsung mencoba produk yang dikampanyekan dengan berbagai pendekatan. Strategi ini kemudian diwujudkan dengan adanya kampanye Youtube Broadcast Box. Menurut Venus (2004), pemilihan taktik sebenarnya hanya didasarkan pada dua fungsi yaitu fungsi menghubungkan dan fungsi meyakinkan. Pertama, taktik mengidentifikasi dan menghubungkan program kampanye dengan sasaran melalui media komunikasi tertentu. Selanjutnya, taktik meyakinkan sasaran melalui kekuatan pesan komunikasi hingga membuat sasaran berpikir, percaya dan bertindak sesuai dengan tujuan kampanye.

Terdapat beberapa taktik yang digunakan untuk Youtube Indonesia untuk mewujudkan strategi yang telah mereka buat. Pertama, mengadakan konfrensi pers untuk menyebarkan informasi tentang adanya kampanye Youtube Broadcast Box. Konfrensi pers ini dilakukan dengan cara mengirim email blast dan juga menghubungi wartawan tertentu secara personal perihal adanya kampanye Youtube Broadcast Box. Kedua, membangun Youtube Broadcast Box yang menjadi ikon untuk menarik minat pengunjung untuk datang ke kampanye, hal ini dilakukan karena Youtube Indonesia ingin 
mengadakan kampanye yang unik untuk mempromosikan produknya dan menghilangkan persepsi di masyarakat bahwa menggunakan platform Youtube itu bukan hal yang susah. Ketiga, untuk mendekatkan diri kepada konsumen loyal maka Youtube Indonesia pun mengadakan workshop, workshop ini bertujuan untuk menjawab segala permasalahan yang dimiliki kreator dan komunitas kreatif lokal tentang platform Youtube. Workshop ini tertutup hanya untuk youtuber yang serius ingin mengembangkan channelnya dan dilihat Youtube Indonesia berpotensi untuk dibina.

\section{6) Alokasi Waktu dan}

\section{Sumber Daya}

Menurut Gregory (2000), ada dua faktor utama yang saling berkaitan yang harus diamati ketika mempertimbangkan skala waktu. Pertama, tenggat waktu (deadline) harus di identfikasi sehingga tugas - tugas yang dihubungkan dengan suatu proyek dapat diselesaikan tepat waktu. Kedua adalah sumber daya yang tepat perlu dialokasikan sehingga tugas tugas yang ada dapat diselesaikan. Dalam merencanakan skala waktu kampanye, Youtube Indonesia memiliki perencanaan jadwal yang dilakukan secara terstruktur. Pembuatan jadwal pelaksanaan strategi ini tidak berfokus pada kuantitas yakni intensitas kegiatan, namun berfokus pada kualitas kegiatan yang sesuai dengan tujuan dari strategi ini. Youtube Indonesia membuat alokasi waktu yang dituangkan dalam tabel perencanaan waktu. Tabel berbentuk perencanaan waktu bulanan dan harian. Tabel perencanaan harian berfokus pada kegiatan yang direncanakan dalam suatu kota sedangkan tabel perencanaan bulanan berfokus pada jangka waktu pelaksanaan kampanye secara keseluruhan. Pemebentukan perencanaan waktu ini diperjelas Venus (2004) bahwa salah satu teknik yang dapat digunakan untuk perencanaan waktu adalah dengan menggunakan Critical Path Analysis (CPA). CPA menganalisis semua komponen pelaksanaan yang terdapat dalam sebuah program secara mendetail. CPA sangat baik digunakan untuk perencanaan waktu program kampanye satu persatu, atau per kegiatan. Sedangkan untuk program kampanye secara keseluruhan dapat digunakan perencanaan waktu tahunan, atau perencanaan waktu per semester yang dituangkan ke dalam tabel perencanaan waktu.

Selain perencanaan waktu, hal penting lainnya yang harus ada dalam perencanaan kampanye adalah sumber daya. Sumber daya sendiri disini dikelompokkan menjadi tiga bagian yaitu sumber daya manusia, biaya dan peralatan. Youtube Indonesia membutuhkan banyak sumber daya manusia pada kampanye diselenggarakan di beberapa kota besar ini. 
Youtube Indonesia membutuhkan banyak sumber daya manusia sendiri karena staff Youtube Indonesia yang sangat sedikit sehingga tidak memungkinkan untuk bisa menjalankan program kampanye sebesar ini. Maka dari itu Youtube Indonesia menyewa sebuah Event Organizer untuk membantu agar kampanye ini bisa terlaksana dengan baik. Event Organizer disini bertugas untuk membangun box dan menjadi staff tambahan seperti operator laptop dan berjaga di box. Penyusunan anggaran diperlukan untuk mengetahui seberapa banyak dana diperlukan dalam rangka membiayai suatu program humas. Dalam hal ini, pihak Youtube Indonesia mengalokasikan biaya secara khusus dalam program kampanye Youtube Broadcast Box ini. Alokasi biaya dibuat dalam laporan tertulis ke dalam laporan keuangan yang nantinya akan dipertanggungjawabkan kepada manajemen Youtube.Yang terakhir, yang tidak kalah penting adalah sumber daya peralatan. Dalam hal ini Youtube Indonesia, sangat concern terhadap pengalokasian dan untuk peralatan karena dana yang dibutuhkan untuk peralatan sangat besar mengingat di dalam kampanye Youtube Broadcast Box terdapat beberapa program acara. Setiap program punya settingan stage khusus dan juga membutuhkan banyak peralatan elektronik seperti laptop dan pengeras suara. Peralatan tentunya merupakan salah satu bagian dari kampanye yang perlu dipersiapkan secara matang oleh Youtube Indonesia.

\section{7) Evaluasi dan Tinjauan}

Disini bentuk evaluasi yang direncanakan oleh Youtube Indonesia adalah dalam bentuk data statistik. Setelah acara selesai dilaksanakan di suatu kota maka bentuk evaluasi yang dilakukan adalah menghitung jumlah pengunjung yang datang dan jumlah hasil upload video yang masuk pada hari dilaksanakan kampanye tersebut kemudian dilakukan evaluasi berkala dengan cara menghitung jumlah upload video ke Youtube kurang dilakukan selama 6 bulan lamanya setelah kampanye selesai dilakukan.Menurut Gregrory (2000), alat yang sangat berguna dalam melakukan evaluasi program PR adalah dengan evaluasi model makro. Model tersebut membentuk sebuah piramida. Bagian dasar piramida itu adalah input, yang pada dasarnya merupakan informasi dan perencanaan sementara pada bagian puncaknya adalah tujuan yang berhasil dicapai.

\section{Pelaksanaan Kampanye Youtube Broadcast Box}

1) Perekrutan dan Pelatihan Personal Kampanye

Disini Youtube Indonesia menyewa sebuah Event Organizer untuk membantu mereka dalam proses pelaksanaan kampanye. Event Organizer ini mereka anggap sudah profesional dan siap pakai 
karena mereka biasa bergelut dalam bidang event ini. Namun untuk penjelasan lebih dalam tentang kampanye sendiri maka Youtube Indonesia mengadakan briefing selama 3 hari sebelum dimulainya kampaye dan juga diadakan briefing setiap acara diadakan di setiap kota. Namun, berdasarkan hasil pengamatan penulis ketika proses perencanaan berlangsung terlihat banyak kesalahan yang sebenarnya bisa dihindari. Hal tersebut dapat dilihat dari tidak teraturnya barisan ketika mengantri untuk masuk ke broadcast box yang dilanjut terlalu lamanya setiap orang yang masuk ke dalam broadcast box menyebabkan antrian semakin menumpuk. Kemudian ketidaktahuan Event Organizer apabila kreator dan komunitas kreatif lokal mempunyai free pass untuk langsung bisa masuk box tanpa mengantri, menyebabkan segmentasi utama yaitu kreator dan komunitas kreatif lokal juga harus ikutan mengantri bahkan diantara mereka ada yang memilih pulang karena terlalu lama mengantri. Hal ini sangat disayangkan mengingat sebelumnya Youtube Indonesia sudah melakukan briefing dengan pihak EO dan pihak EO yang mereka pilih pun sudah memiliki banyak pengalaman dalam mengurus event.

"Penentuan siapa saja yang akan terlibat sebagai pelaksana kampanye merupakan langkah awal dalam melaksanakan kampanye. Orang - orang yang akan menjadi personal kampanye harus diseleksi dan diteliti dengan memperhatikan aspek motivasi, komitmen, kemampuan berkerjasama, dan pengalaman yang bersangkutan dalam kerja sejenis. Di samping ketrampilan tersebut, personel setiap kampanye juga harus dipastikan memahami tema, objek dan tujuan kampanye. Dengan begitu ketika muncul berbagai pertanyaan kepada mereka seputar kampanye yang berlangsung kepada mereka, maka jawaban yang keluar akan senada dan konsisten dengan desain kampanye keseluruhan.” (Venus, 2004:200).

\section{2) Mengkonstruksi Pesan}

Venus (2004), pesan kampanye memiliki berbagai dimensi yang meliputi pesan verbal, nonverbal, dan visual. Namun apapun dimensinya, kesederhanaan harus terus diutamakan kaprena dapat membuat pesan menjadi mudah dipahami sekaligus diingat. Dalam mengonstruksi pesan pelaku kampanye juga harus memperhartikan bagaimana pesan tersebut diorganisasikan karena pengorganisasian pesan akan mempengaruhi bagaimana khalayak merespons pesan (Venus,2004:201). Pada kampanye Youtube Indonesia, pesan juga diorganisir agar dapat mencapai khalayak yang lebih luas. Hal ini dilakukan dengan cara setiap pengunjung yang datang diajak 
untuk

menulis

hastag

\#areyouthenextdigitalcreator pada akun sosial media mereka. Hal ini diharapkan dapat menaikkan citra positif Youtube dan juga menjangkau khalayak yang lebih luas lagi.

\section{3) Menyeleksi Penyampai Pesan Kampanye \\ Penyampai pesan kampanye yang} dipilih oleh Youtube Indonesia adalah Niken Sasmaya dimana beliau berperan sebagai pemandu acara, mempresentasikan Youtube Partnership Program serta menjelaskan fungsi dan keunggulan pada platformYoutube itu sendiri. Youtube Indonesia juga menghadirkan bintang tamu yaitu Youtuber - Youtuber yang sudah terkenal karena mereka dirasa perusahaan mampu memberi informasi dan mempengaruhi serta memotivasi konsumen untuk loyal terhadap brand. Hal ini sejalan dengan pernyataan yang disampaikan oleh Venus dalam buku manajemen kampanye.

“Keputusan untuk menentukan siapa pelaku atau penyampai pesan kampanye ini sangat penting karena merekalah aktor yang akan berhadapan langsung dengan publik. Pada umumnya faktor pokok yang harus diperhatikan dalam menyeleksi pelaku kampanye adalah kesuaian tokok tersebut dengan objek kampanye, media yang digunakan, dan kredibilitas yang bersangkutan di mata publik.” (Venus,2004:202).

\section{4) Menyeleksi Saluran Kampanye \\ Dalam hal menyeleksi saluran} kampanye, Youtube Indonesia lebih mengandalkan media sosial dalam menyebarkan informasi. Media sosial mereka pilih karena khalayak mereka kebanyakan adalah pengguna media sosial aktif dan juga karena perusahaan sendiri bergerak di bidang web developer seperti Google dan Youtube sehingga biaya yang dikeluarkan bisa dipangkas dalam hal menyebarkan informasi. Media sosial yang Youtube Indonesia gunakan antara lain Facebook, Twitter, Youtube dan Google Plus. Selain media sosial, Youtube Indonesia juga menggunakan radio untuk menyebarkan informasi, channel radio yang mereka pilih adalah channel yang paling banyak didengar di kota tempat kampanye akan dilaksanakan. Menurut Venus (2004), menyeleksi media mana yang akan digunakan sebagai saluran kampanye harus dilakuka dengan penuh pertimbangan dalam pemilihan media kampanye diantarannya: jangkauan media, tipe dan ukuran besarnya khalayak, biaya, waktu, dan tujuan serta objek kampanye. Di samping itu faktor lain yang juga perlu mendapat perhatian adalah karakteristik khalayak, baik secara demografis, psikografis, maupun geografis. Pola penggunaan media khalayak (media 
habit) juga harus diperhitungkan untuk memastikan media apa yang biasanya digunakan khalayak.

5) Tindakan dan Pemantauan Kampanye

Tindakan dan pemantauan program kampanye Youtube Broadcast Box secara keseluruhan berjalan dengan baik. Alasan penulis mengatakan demikian dikarenakan program kampanye ini bersifat interaktif antara konsumen dengan perusahaan yaitu Youtube Indonesia. Youtube Indonesia dengan tanggap berusaha memberika informasi yang sejelas mungkin agar dapat menjawab permasalahan yang dimiliki konsumen tentang produk. Informasi yang diberikan oleh para pakar baik itu pembicara perwakilan dari youtube dan juga youtuber profesional tidak hanya diterima namun juga konsumen juga berinisiatif mengaggapi ataupun memberika masukan terhadap program kampanye agar lebih sering diadakan di kota besar lainnya. Hal ini sejalan dengan pernyataan dari Venus (2004), yang menyatakan bahwa tindakan kampanye bersifat problem solving oriented artinya segala bentuk tindakan dalam proses kampanye diarahkan untuk mencapai tujuan yang ditetapkan.

Dalam proses pelaksanannya sendiri pemantauan dilakukan oleh manajer lapangan yaitu Niken Sasmaya. Beliau bertugas memantau jalannya kampanye dengan cara memantau langsung perkembangan acara di setiap sesi seperti pada bagian broadcast box, bagian workshop, jalannya press confrence. Petugas yang berada di lapangan pun cukup kooperatif dan menjalankan tugasnya dengan baik, namun terkadang adanya karena terbatasnya pengetahuan personil EO tentang produk menyebabkan informasi yang di dapat khalayak menjadi minim. Namun secara keseluruhan staff Youtube Indonesia dan petugas dari EO yang berada dilapangan bekerja dengan kooperatif sehingga program kampanye Youtube Broadcast Box dapat berjalan dengan baik.Hal ini sesuai dengan konsep dari Venus (2004), yang menyatakan bahwa kegiatan kampanye bukanlah tindakan one man show melainkan kegiatan yang didasarkan pada kerja tim. Keberhasilan kampanye ditentukan oleh bagaimana pelaksana kampanye bertindak secara integratif dan koordianatif. Koordinasi ini tidak hanya dilakukan dengan sesama pelaksana kampanye melainkan juga dengan berbagai pihak terkait yang akan turut mempengaruhi kelancaran dan keberhasilan pencapaian tujuan kampanye.Penjelasan di atas menjelaskan bahwa peranan manajer kampanye atau yang Youtube Indonesia sebut manajer lapangan sangatlah penting untuk mengatur koordinasi. 


\section{6) Laporan Kemajuan}

Laporan kemajuan yang dimiliki oleh Youtube Indonesia sifatnya adalah data dalam bentuk angka. Laporan ini hanya berisi berapa jumlah pengunjung yang datang dan juga jumlah video yang berhasil di upload pada setiap kota. Alangkah lebih baiknya apabila apabila laporan yang dimiliki bukan hanya berdasarkan goals yang ingin dicapai dalam bentuk angka tetapi juga data dari lapangan yang berbentuk wawancara dengan konsumen atau bisa juga menyebarkan angket tentang kampanye kepada konsumen yang sedang mengikuti acara ini sehingga hasil evaluasi yang didapat semakin banyak dan beragam. Hasil evaluasi yang beragam dari dalam berbagai bentuk data, diharapkan dapat menyempurnakan kampanye yang dibuat selanjutnya.Hal ini juga diperkuat dengan pernyataan Venus (2004) yang menyatakan bahwa dalam laporan kemajuan umumnya dimuat berbagai data dan fakta tentang berbagai hal yang telah dilakukan selama masa kampanye. Data yang disajikan umumnya bukan hanya berkaitan realisasi rencana kampanye tapi juga mencakup berbagai temuan lapangan, baik yang positif atau negatif.

\section{Evaluasi Kampanye Youtube Broadcast Box}

Youtube Indonesia menggunakan hasil kuantitatif untuk mengevaluasi hasil kampanye. Evaluasi ini digunakan karena Youtube Indonesia juga menggunakan data berbentuk angka sebelum sebagai pembanding data sesudah kampanye. Mereka melakukan evaluasi dengan cara menghitung data pengunjung dan hasil jumlah upload video di setiap kota ditambah dengan evaluasi jumlah upload setelah kampanye berakhir. Hasil evaluasi yang didapat bahwa kenaikan presetase jumlah upload video hanya sekitar 15\% jauh di bawah goals yang ditetapkan oleh Youtube Indonesia yaitu sekitar 30\%. Sayangnya berdasarkan penjelasan di atas terlihat bahwa Youtube Indonesia kurang mengevaluasi kampanye mereka secara mendalam. Padahal menurut, Morrisan (2005), evaluasi keberhasilan program humas tidak bisa dilihat hanya dari angka, pujian dan liputan media massa. Evaluasi yang signifikan terhadap suatu program kehumasan haruslah dilakukan berdasarkan pengukuran secara ilmiah mengenai peningkatan kesadaran atau perubahan pendapat, sikap dan tingkah laku khalayak mengenai organisasi atau perusahaan.

\section{SIMPULAN}

1) Tahap perencanaan kampanye Youtube Broadcast Box sudah dilaksanakan oleh Youtube Indonesia sebagai langkah awal membuat sebuah kampanye public relations namun. Hal ini ditunjukkan melalui adanya tahapan 
menganalisis permasalahan yang dilakukan melalui survey.

2) Tahap pelaksaan kampanye Youtube Broadcast Box ini dimulai dari perekrutan dan pelatihan personel kampanye dilakukan dengan cara bekerjasama dengan pihak Event Organizer untuk dapat menyampaikan pesan kampanye agar dapat diterima khalayak melalui seleksi media yang digunakan untuk menyebarkan informasi tentang adanya kampanye Youtube Broadcast Box di media sosial dan media massa elektronik.

3) Tahap evaluasi dalam kampanye program Youtube Broadcast Box yang pertama kali dilakukan dapat dinilai berhasil yang dibuktikan melalui presentase jumlah video yang diupload ke platform Youtube setiap bulannya secara harian.

\section{DAFTAR PUSTAKA}

Brakus, J.J., Schmit, B.H \& Zarantonello, L.(2009). "Brand Experience: What is it? How is it Meassured? Does it Affect Loyalty? Journal of Marketing, Vol. 73, No.2, pp.

Gregory, Anne. (2000). Public Relations Dalam Praktik. Jakarta: PT. Gelora Aksara Pratama.

Margono, S. (2005). Metode Penelitian Pendidikan : Komponen MKDK. Jakarta: Rineka Cipta.

Morrisan, M.A. (2005). Manajemen Public Relations. Bandung: Prenada Media Grup Divisi.

Mulyana, Deddy. (2005). Ilmu Komunikasi: Suatu Pengantar. Bandung: Remaja Rosdakarya.

Nazir, Mohammad. (2006). Metode Penelitian. Bogor: Ghalia Indonesia.

Sugiyono. (2011). Metode Penelitian Kuantitatif, Kualitatif, dan R\&D. Bandung: Alfabeta.

Venus, Antar. (2004). Manajemen Kampanye. Bandung: Simbiosa Rekatama Media. 